1

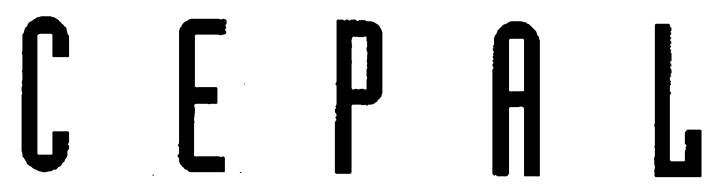

REV IE W

NUMBER 49

APRIL 1993

SANTIAQO, CHILE

ANIBAL PINTO

Director

EUGENIO LAHERA

Techical Secretary

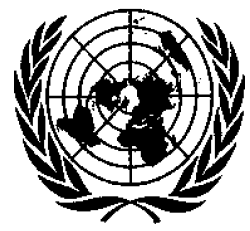

UNITED NATIONS 
C ONTENTS

Women in the region: major changes Miriam Krawczyk

The Pacific Basin and Latin America

Dae Won Choi

Strategic management, planning and budgets

Juan M. F. Martin P. and Arturo Núnez del Prado

The internationalization of Latin American industrial firms

Wilson Peres Núñez

Water property rights and the State: The United States experience

Carl J. Bauer

Poverty and adjustment: the case of Honduras

Jorge Navarro

The trade union system: its background and future prospects

Fernando Calderón G.

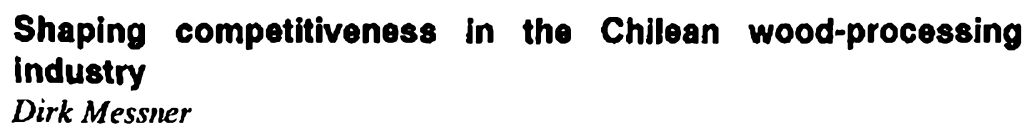

Privatizations and social welfare

Robert Devlin

Guldelines for contributors to CEPAL Reviow 


\section{Water property rights and the State: The United States}

\section{experience}

\section{Carl J. Bauer}

Visiting doctoral candidate, Department of Jurisprudence and Social Policy, Boalt Hall School of Law, University of California (Berkelcy)
The nature of property rights regimes has great influence on patterns of water and other natural resource development, and hence on economic development in general. Although in capitalist societies property rights are predominantly "private," their actual form and content are shaped by a wide range of political, economic, legal, and social institutions, so that the boundary between "public" and "private" is often very hard to define. The case of water is especially problematic: its peculiar physical characteristics mean that private rights are typically rights to use rather than ownership, and the need for public regulation to coordinate users is inescapable. In addition it is commonly believed that water rights regimes are much affected by geographic conditions: primarily whether the climate is wet or dry. This paper presents a North American case study of property rights and State involvement in water development that has several features similar to contemporary Latin America: geographic contrasts, economic transformation from agricultural to urban/industrial development, and political conflict over the role of the State and the limits of private property. The case is that of the State of Washington from the late 19th century to the Second World War, characterized by two contradictory water rights doctrines and a dramatically changing balance between irrigation and hydroelectricity. Several general lessons for the Latin American region can be drawn from this case: i) geographic conditions are much less important to legal doctrine and institutions than the redefinition and security of private rights needed to stimulate capital investment; ii) the importance of water development for regional economic growth depends on State involvement to overcome the limitations of the private sector; iii) private property can take several different and incompatible forms: a point which both its proponents and critics often ignore; iv) a private property regime geared to dynamic economic development can only be established and maintained with the active support of State intervention and administration, and v) such a regine can so effectively overcome the geographic and social obstacles presented by Nature 10 private property that the legal and institutional reforms needed to ensure "environmentally sustainable development" will probably have to be more fundamental than is often supposed. 


\section{I}

\section{Introduction}

In Latin America and elsewhere, the nature of property rights regimes has great influence on patterns of water and other natural resource development, and hence on regional economic development in general. ${ }^{1}$ In capitalist societies, of course, property rights are predominantly "private," but their actual form and content are shaped by a wide range of political, economic, legal and social institutions. How to define the boundary and relations between "public" and "private" thus becomes a crucial and contested question.

In the case of water the question is particularly complicated. In part this reflects water's physical nature -its mobility, fluidity, versatility and vital importance give it an inherently public character. Property rights regarding water are also affected by different geographic conditions. The question of whether the climate is arid or humid is widely believed to exert a strong influence on water rights regimes: the scarcity or abundance of water influences which land uses or other economic activities are most feasible, and this in tum influences legal rules on water use and control. This belief may become a sort of "environmental determinism", according to which societies in arid climates the world over tend to develop similar systems of water law which differ markedly from those developed by societies in humid climates.

The premise of this paper is that Latin American policy-makers can draw some important conclusions about property rights and the role of the State in water resource development from a case study of what happened in the State of Washington from the late 19th century to the Second World War. Despite the evident differences, this case presents several features that are sufficiently similar to contemporary Latin American conditions to be useful: geographic variability and contrasts; economic transformation from primarily agricultural and resource-extractive activities to more urban and industrial development; and political conflict over the proper role for the State in this process and over the nature and limits of private property rights. While the study is limited to water resources, it is suggested that it offers more general lessons about the relation between private property and the State, and about the prospects for environmental sustainability under conditions of capitalist development.

\section{II}

\section{Water resource development and}

\section{policy issues in Latin America}

Latin America is characterized by wide variations of environmental and climatic conditions. This is so not only between different nations -e.g., Mexico is generally more arid than Brazil- but also within nations, as nearly all of them have both arid and humid regions -e.g., northern vs. southern Mexico, western vs. eastern Argentina, etc. Such variety, when combined with the geographic distribution of different economic activities, leads to a wide range of supply and demand

\footnotetext{
${ }^{1}$ By "regime" I mean both the legal conception of property rights themselves, as well as the associated complex of public institutions through which such rights are concretely expressed.
}

conditions for water resources, and hence of problems for water law, policy, and management.

Notwithstanding such variety, there are several economic, social and political factors that are common to water resource issues in most of Latin America. As identified in a United Nations analysis in 1980, these factors are: growth in both population and economic production; increasing urbanization (i.c., geographic concentration of development); water resources which are abundant but typically distant from population centres; rapid adoption of modern technology; and centralization of both political and 
economic power and decision-making. These combine to produce two principal kinds of water resource problems: i) problems of quantity, regulation of flow, and water and land use conflicts; and ii) urban problems of bad water quality, especially associated with poverty (United Nations/ECLAC/UNEP, 1980). This and subsequent analyses have shown the need for more integrated institutional operations, more equitable distribution of both costs and bencfits of water development, and more effective and participatory long-term planning (see also ECLAC, 1989). Reaching any of these objectives will depend in large part on the nature of property rights regimes and the role of the State. 2

\section{III}

\section{Contradictions between private property}

\section{and economic development}

Private property is an idea and institution that has been much argued and fought over. Both its proponents and critics, however, have often failed to distinguish among different kinds of and justifications for private property, thereby mixing together arguments that are not always compatible and may even be contradictory. 3

The classic political argument, for example, is that private property is the best guarantee of individual liberty, delimiting a private sphere of activity within which State intervention is prohibited. This argument may also have moral or philosophical aspects, since such liberty includes the right to individual selfexpression, free will, and the like (Ramos, 1991). The classic economic arguments are twofold, but need not go together: the first is that private property stimulates production and productivity by giving rightsholders incentives both to labour and to invest wealth, since they are guaranteed the fruits of their activities. The second is that such property is vital to the operation of markets, since the exchange of goods and services is impossible unless people have exclusive and alienable rights to their possession. ${ }^{4}$ Note that these two arguments, although commonly associated, are logically independent since production incentives do not necessarily imply a market economy.

These political and economic arguments come into fundamental conflict when a private property regime is combined with rapid economic growth and industrialization. Under such dynamic conditions of capitalist development, the need for security of existing private rights clashes with the demand for economic and technological change, which involves newer claims to resources. This has been the case in many parts of Latin America during the 20th century, especially since the Second World War, and is also clearly illustrated by the example of the 19th century United States. During that century U.S. law underwent a fundamental transformation, from a system of customary rules inherited from England, based on substantive notions such as "fairness" and "equity," to a utilitarian conception in which laws were used as policy instruments to stimulate economic expansion. Such diverse areas of law as property, contracts, torts, and corporations were reshaped to free private initiative from its traditional social obligations, to promote what the legal historian Willard Hurst called the "release of creative energy." Property law in particular lost its traditionally static character, rooted in protecting the "quiet enjoyment" of land ownership, to become both more dynamic and more abstract: existing vested rights were increasingly disregarded in favor of newer commercial ventures, which helped to

\footnotetext{
${ }^{2}$ In this paper I am concerned with issues of water quantity rather than quality; nonetlicless, many of my conclusions are directly applicable to the latter as well, in that they deal with the relation between State authority and different kinds of privale property rights.

${ }^{3}$ Useful surveys of property theory are given in Macllicrson (ed.), 1978 and Reeve, 1986.

4 The North American "law and economics" school argues, therefore, that the principal function of property law should be to remove obstacles to private bargaining, thereby increasing cconomic efficiency through market mechanisms. This requires that property rights be exclusive, iransferrable, and universal, i.e., that as many things as possible be treated as pure commodities. See Ackerman (cd.), 1975, Cooter and Ulen, 1988, and Posner, 1977.
} 
fuel economic expansion. 5 Water rights, as we will see below, played a leading role in this transformation.

These changes in property law resulted from repeated State intervention. The chronic scarcity of capital in the 19th century U.S. induced state and national legislatures to grant special legal privileges to any private interests that would stimulate economic development, e.g. by building infrastructure -roads, canals, bridges, etc.- or by exploiting natural resources in the public domain. Prominent among these "legal subsidies" to private parties was the grant of the government's eminent domain powers, which allowed the expropriation of private property when necessary for a "public use" or "public purpose." 6 Despite their usual protection of vested rights, the courts supported this legislative policy because of the shared conviction that economic growth was a "public purpose" regardless of the distributional consequences (Scheiber, 1973; Scheiber and McCurdy, 1975). By the end of the century, however, legal policies of this sort had resulted in such concentration of economic and political power, and therefore social tension and inequality, that reform movements were able to modify the legal system in the direction of increased public regulation (Hurst, 1956).

\section{IV}

\section{Water as a problem for private property regimes}

Water is a substance whose peculiar characteristics blur the public/private distinction and pose serious problems for private property as usually understood. "Water is life" -vital to biological survival and to a wide range of economic and social activities. Its fluidity and mobility link together different ecosystems while making it hard to capture and hold. The physical connections are unavoidable: how someone uses water in one part of a hydrologic system directly or indirectly affects how other people use it somewhere else.

Because of these physical and social characteristics, private rights regarding water have nearly always been defined as rights to use rather than ownership, with the latter remaining public. Different people may have use-rights to the same "parcel" of water at different times or places in a hydrologic system. Water rights are thus fundamentally conditional rather than exclusive, fitting into a set of relationships that express overlapping claims to the uses and

\footnotetext{
${ }^{5}$ The major references for this legal transformation are Horwitz, 1977 and Hurst, 1956. Two additional comments of Hurst's are particularly interesting: he argued that private property, after having been primarily a political idea in the 18 th century, became primarily an economic idea in the $19 \mathrm{th}$; and he explained the overall legal evolution by pointing to the market as the dominant image and idea of 19 th century U.S. society.

By the "abstract" nature of property I refer to the increasingly universal tendency, by the late 19 th century and beyond, 10 recognize claims to natural resources based on stock and bond ownership, debt and credit instruments, and so forth, rather than concrete use or other direct activity. See the essays collected in MacPherson (ed.), 1978.
}

benefits of a shared resource. Such rights are hard to treat as commodities or to subject to market mechanisms, since exchanges usually affect other rightsholders who are not part of the immediate deal. ${ }^{7}$ Use-rights in general, therefore, can be seen as an inherently non-capitalist form of property (MacPherson (ed.), 1978) -inherently, but not inalterably, as I will argue below. ${ }^{8}$

\footnotetext{
${ }^{6}$ This must not be confused with the doctrine of dominio eminente found in some Latin American countries, which refers to inalienable public/State ownership of certain key resources, particularly minerals. The U.S. usage refers to the State's power to take private property for public purposes subject to the payment of compensation.

${ }^{7}$ These third-party effects have led one prominent "law and economics" figure from the University of Chicago to argue that water is an exception to the principle that property should be shaped by and for the market (Posner, 1977). Sec also MacPherson (ed.), 1978 and Reeve, 1986.

${ }^{8}$ The problems posed by water use-rights, far from being limited 10 water, indicate a deeper weakness in the neo-classical theory that forms the basis of the North American "law and economics" school (or the so-called "property rights" school): the definition of valuc. Neo-classical economists assume that "value" means "market or exchange value," and argue that it is changes in such value that force changes in property rights regimes. Recent work in the "institutional economics" tradition, in contrast, argues the reverse, i.e., that changes in property relations, expressed through legal, political and economic processes, determine how value is defined. Both schools of thought agree, however, that how market institutions work depends on property arrangements set up beforchand. See Bardhan, 1989; Bromley, 1982; MacPherson (ed.), 1978, and Reeve, 1986.
} 
Besides the juridical fact of public ownership, the practical need for coordination and control of water uses is also evident. Some form of public regulation is thus both indispensable and legitimate. "Public," however, can mean different things and different scales, from a local community organization to a centralized State. The institutions in question may be predominantly political, administrative, judicial, or even religious or cultural in nature. These different possibilities have markedly different effects on the way decisions are made and conflicts resolved, on what kinds of arguments are brought to bear, and on how different social groups can influence the process.

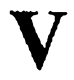

\section{Water rights doctrines in the 19th century United States}

The history of U.S. water rights law illustrates the wider 19th century transformation of property mentioned above, as well as the influence of different climatic conditions on such rights. The following summary will set the stage for the case study that makes up the next part of this paper.

Upon winning national independence, for reasons of utility and shared cultural heritage the U.S. initially adopted almost the entire body of English common law, including water rights law. ${ }^{9}$ The English legal tradition had developed the doctrine of riparian water rights, according to which any owner of riparian land -i.e. land bordering or containing a water-body such as a stream, river, or lake- had the right to use that water. This riparian right was a private property right which derived from, and was supplemental to, the ownership of land. But because all riparian landowners, regardless of amount of property or date of title, had an equal right to use the water touching their land, the courts developed rules prohibiting them from consuming it without returning it, and mandating its equal sharing among all rights-holders. Since both Britain and Eastem North America were humid regions, agriculture and livestock raising could rely on rainfall, and the main uses of water resources until the 19th century were for navigation and fisheries; both of these required continued and uninterrupted

\footnotetext{
${ }^{9}$ This did not include constitutional law, of course, which did not exist in England; in this area Americans developed an innovative federal system, distinctive relationships among the legislative, judicial, executive, and later administrative branches of government, and a Bill of Rights.
}

flow, which was guaranteed by the so-called "natural flow" doctrine. In this way the riparian doctrine expressed values of social equality and cooperation -at least among property owners- and "an attitude of non-interference with nature....[which] therefore was biased against economic development." (Worster, 1985, p.88)

It was this bias against development that gave water rights their leading role in the transformation of American property law. Beginning in the $18 \mathrm{th}$ century, the Industrial Revolution generated an increasing demand for water-power for use in the expanding grain, saw, and textile mills, as well as iron foundries. Developing water-power required building dams that blocked natural streamflow and created reservoirs, then letting the water through at irregular intervals. Since this was a clear violation of others' riparian rights, both upstream and downstream, for many years the courts routinely ruled against mill-owners in lawsuits; by the late 18 th and early 19 th centuries, however, they came to approve new state legislation that gave power developers priority over riparian landowners. This change of policy and principle was justified by the utilitarian concern to promote industrialization and economic growth (Horwitz, 1977; Scheiber, 1973).

Aside from this modification the riparian doctrine retained its key features of prohibiting off-stream consumption and ensuring equal sharing of available water. In the arid West, however, these rules in turn became major obstacles to development after 1850 , as the westward march of European American settlement reached the Great Plains and Rocky Mountains, and the Gold Rush sparked migration to California. In all of those places agriculture required irrigation, which 
was impossible if consumptive water use was prohibited, and in any case precipitation was so scarce and unpredictable that equal sharing made water rights very uncertain. These were serious disincentives to annual cultivation, let alone investment in canals and other irrigation works. As a result, in the 1870 s and 1880 s a new doctrine known as "prior appropriation" was developed in the Western United States, under which water rights referred to specific quantities of water, which could be consumed offstream and which were ranked in order of priority according the principle "First in time is first in right."10 In this way, at least the earliest ("senior") appropriators had secure claims in all but the worst drought years, and more junior appropriators worked down the order of priority each season until there was no water left. These rights were private property and, unlike riparian rights, could be bought and sold independently of land ownership.

The most common explanation of the spread of the appropriation doctrine throughout the Western U.S. is the classic environmental argument: the change in property rights was required by the needs of agriculture in an arid climate, showing the pragmatic ingenuity of the American pioneer (Webb, 1931). The associated changes in State administrative structure, if mentioned at all, are generally considered secondary (Dunbar, 1983). In the following case study I will argue that this interpretation is wrong on both counts: it overstates the importance of climate, while it understates the changed role of the State and ignores the ways in which the new regime overcame some of the obstacles presented by water to capitalist forms of property.

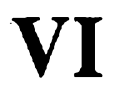

\section{North American case study: Washington State, 1890 - 1940}

The State of Washington, from the late 19th to mid20th centuries, provides an especially useful illustration of the legal, geographic and political/economic issues discussed above. Located on the Northwest coast of the U.S., it contains both humid and arid sections, divided by the Cascade Mountains: the forner lie between that range and the Pacific Ocean, while the latter stretch east from that range to the Northern Rocky Mountains of Idaho. Conflicts arose from the contrasting climatic conditions and from disagreement over the legitimacy of different forms of private property, as for several decades the State maintained both the riparian and appropriation water rights doctrines simultaneously, abandoning the former much later than other Western states. The outcome of these conflicts was a property regime designed to maximize capital investment, whose functioning depended on comprehensive State administration. During the same period the new technology

\footnotetext{
${ }^{10}$ This principle had its roots in California mining claims, in which private individuals competed for parts of the public domain (Pisani, 1984).
}

of hydroelectricity emerged and grew rapidly, although State policy and intervention in water resource development remained preoccupied with irrigation. The eventual transformation of this State role both responded to, and had a major impact on, the pattern of regional economic development. 11

\section{Conflicting water rights doctrines and the move towards administrative rationalization}

Washington's contradictory. approach to water rights was established in 1889, the year it became a state, and in part involved an institutional conflict between the legislature and the courts. The legislature responded to demands from irrigators and to the example of other Western states by declaring that water use-rights "may be acquired by appropriation, and as between appropriations the first in time is the first in right." 12 When

\footnotetext{
${ }^{11}$ I focus on Washington State law, not Federal law, for two reasons: i) under the U.S. Constitution non-navigable waters fall under the former's jurisdiction; and ii) State law provides a more accurate picture of local and regional dynamics.

${ }^{12}$ Laws of 1889-1890; Laws of 1891, Chap. 142.
} 
adopting its Constitution, however, Washington followed the usual practice of adopting the existing body of English and American common law, which included the riparian doctrine of water rights. Thus, the State Supreme Court, as guardian of the Constitution, refused to recognize appropriation rights except in respect of waters on Federal public lands, where such rights were recognized by national law. ${ }^{13}$ Although legally consistent, this distinction became a nightmare in the arid eastern part of the state, where most watersheds contained both public and private lands. Repeated lawsuits asked the Court to abandon the riparian doctrine as "not applicable to the arid portions of the state," but in an 1897 landmark case the Court rejected this environmental argument, holding that:

"It certainly cannot be true that a difference in climatic conditions or geographical position can operate to deprive one of a right of property vested in him by a well-settled rule of common law." 14

Nonetheless, the Court showed its desire to encourage irrigation by developing the principles of "reasonable" and "beneficial" use in the early 1900 s. With "reasonable use", the Court modified the riparian doctrine's "natural flow" requirement to allow riparian rights-holders to divert and consume some water for irrigation; with "beneficial use" it went further by allowing non-riparians to claim riparians' unused water rights, explaining:

"It is not to the state's interest that the water of a non-navigable stream should be idle or going to waste because one of its citizens, having a preference right to its use, unjustifiably neglects to avail himself thereof, while others stand ready and willing, if permitted, to apply it to the irrigation of their arid lands." 15

\footnotetext{
${ }^{13}$ See, for example, Tenem Ditch Company v. Thorpe (1889) 20 Pac 588; Rigney v. Tacoma Light and Water Company (1894) 38 Pac 147. The Federal laws were the Mining Acts of 1866 and 1870 and the Desert Land Act of 1877. In this and other notes, the abbreviation "Pac" refers to judgments of the Supreme Court of the State of Washington compiled in the official Western U.S. review of jurisprudence, The Pacific Reporter (National Reporter System - State Series, St. Paul, West Publishing Co.). The number before the abbreviation indicates the volume and the number after, the page.

${ }^{14}$ Benton v. Johncox (1897), 49 Pac 495, 496-7.

${ }^{15}$ State ex rel Liberty Lake Irrigation Company v. Superior Court of Spokane County (1907) 91 Pac 968, 970.
}

Riparians objected strongly, of course, but the Court repeatedly asserted "the necessity of beneficial use by the riparian owner," contradicting its geographic reasoning quoted above (see footnote 14) by saying that this met "the general needs and welfare of the state, especially in the arid and semi-arid regions," and "deprived no one of any rights which he may justly claim." 16

Despite these judicial decisions, after 1900 there were a series of political attempts to clarify the situation by adopting a State Water Code based on the appropriation doctrine. The main forces behind the proposal were irrigation interests in eastern Washington (including the U.S. Reclamation Service, see below), who argued that new investment and development, which depended especially on Eastern capital, was prevented by the uncertainty of water rights and the open-ended claims of riparians to future water use. The Chairman of the Governor's Water Code Commission, for example, criticized the inaction of such riparians and said, "It should be the privilege of other people to appropriate and make use of all water then running to the sea and doing nobody any good." An attorney on the Commission agreed:

"In this Western country we have claimed that the proper use of water is what a man's rights should be based on. He should not be permitted to let it run by just because it is pretty to look at or to let ducks swim in it, but some beneficial use should be made of it." He added that "the needs of eastern Washington are based on one theory, to wit, irrigation, [while] the needs of... westem Washington are based on the use of water for power, logging, etc. So we have two divergent interests in water matters in this state." 17

But the political geography was not so simple. The reform efforts were defeated again and again in the Washington legislature from 1905 to 1917, by opponents arguing that such a Code would unconstitutionally expropriate riparians' vested property rights, without compensation. This objection was so wellfounded that it troubled even lawyers who favoured the Code. In addition to riparian landowners in

\footnotetext{
${ }^{16}$ Brown v. Chase (1923), 217 Pac 23, 25-26; Proctor v. Sim (1925), $236 \mathrm{Pac}$ 114, 118. "Beneficial use" has been defined as "in an exclusive manner so as to reap an economic as distinguished from an aesthetic benefit." (Morris, 1956, p. 258).

${ }^{17}$ Letler dated 2 October 1913 to Governor Lister; address by I.P. Englehart to the Washington Irrigation Institute, 1914, both in Govemor Lister's Papers, which are to be found in the Washington State Government Archives, Olympia, Washington (emphasis added by the author).
} 
western Washington, many of the Code's most active opponents were in fact irrigators in eastern Washington who had invested heavily in riparian land and stood to lose much of their property's value if their riparian water rights were no longer protected. Most of their prominent spokesmen were lawyers and businessmen from the eastern city of Spokane. As one of them protested to the Governor, "There is no farmer in the state of Washington but what is attacked by this procedure." 18

The position of hydroelectric power interests was also more ambivalent than it first appeared. Since their water use was non-consumptive, they initially preferred the riparian doctrine, and helped to defeat some early versions of the Code (Dunbar, 1983). Most power development had taken place in humid western Washington, where the riparian doctrine had not presented serious obstacles; although constrained by the rights of both upstream and downstream riparians, power developers could buy those rights if necessary, and the courts consistently supported their exercise for power generation. A 1913 decision is illustrative:

"Where power is desired the rule [guaranteeing natural flow] must yield to the necessity of gathering the water into reservoirs.... Each owner is entitled to a reasonable use, and any interruption in the flow unavoidable by a reasonable and proper use is permissible." 19

But power developers in eastern Washington had had no trouble under the appropriation doctrine either. From 1889 the courts had recognized their claims to waters on public lands, and given them priority over junior appropriators who were irrigators. ${ }^{20}$ Appropriation rights had the added advantage of being frec, as long as there was water available, whereas riparian rights could be secured only by land ownership or by purchase from existing landowners. As a result, a

\footnotetext{
${ }^{18}$ Wilbur Yearsley, letter dated 4 March 1913 , in Governor Lister's Papers.

${ }^{19}$ Sumner Lumber and Shingle Company v. Pacific Power and Light Company (1913), 131 Pac 220, 224. Sec also an earlier case in which a sawmill was awarded substantial damages when an upstream inunicipality reduced the flow: "Whatever of benefit, whether of power or olherwise, comes from the flow of water in the channel of a natural strcam, is a malter of property, and belongs to the riparian owner, and is protected in law just as fully as the land which he owns." City of New Whatcom v. Fairhaven Land Company (1901), 64 Pac 735, 740.

${ }^{20}$ See, for example, Ellis v. Pomeroy Improvement Company (1889), 21 Pac 27; Sander v. Bull (1913), 135 Pac 489.
}

number of riparian spokesmen believed the power interests to be secretly in favour of the appropriation doctrine, since "it would give them all the water rights on non-navigable streams which they now have to pay for." 21

The constitutional argument over property rights was finally resolved in 1917, when the legislature passed a misleading compromise and put its future resolution in the hands of a new state administrative agency. The 1917 Water Code adopted the appropriation doctrine as state law, while inconsistently declaring that this did not "lessen, enlarge, or modify the existing rights of any riparian owner." Those rights, however, became subject to condemnation (expropriation) by other water users, and the requirement of "beneficial use" was made statutory. The most important change was the creation and unprecedented authority of the Office of the State Hydraulic Engineer. This had a number of administrative powers and duties: to review requests for appropriation water rights and issue permits, free of charge, to those whose requests were granted (i.e., if there was water available); to keep a central record of water rights and usage; to supervise stream diversions according to es. tablished rights; to gather hydrologic data to aid in water resource planning; to inspect the engineering safety of dams, canals, and related infrastructure; and -most controversial of all- to take over the courts' function of determining water rights in the cvent of conflicts.

This adjudicative authority was soon challenged in court as unconstitutional. Irrigators whose rights had been denied in onc such conflict argucd that the Code unconstitutionally gave the State Engineer both executive and judicial powers, and that his decision was an uncompensated taking of private property. In 1921 the State Supreme Court strongly disagreed:

[The Code] "was intended to cover the whole field of irrigation and correct the abuses inherent in earlier irrigation methods. [It] appears to be broad enough to include almost any conceivable rights with reference to irrigation....[and] authorizes the hydraulic engineer to control all of the waters of the state for irrigation purposes."

\footnotetext{
${ }^{21}$ See letters daled 27 January 1913, 14 February 1913 and 8 January 1915, in Governor Lister's Papers. Emplasis in original. These letters describe the case of a planned irrigation project in the eastern Cascades which had been blocked because speculators in power development had appropriated the necessary waler.
} 
Two years later the Court confirmed that:

"The Water Code saves all existing rights in land and water. That, however, does not militate against the right of the state, in the exercise of a supervisory control, of administering the use of water for the public welfare."

The Court was equally deferential in 1930 when the legislature amended the Code to specifically mention hydroelectricity (for the first time), and gave the State Engineer the power to decide conflicts between hydroelectric development and other water uses. 22 Thus a water rights system which had originally been designed mainly for irrigation (a consumptive use) proved to be equally suited to hydroelectric power (a non-consumptive use), despite their apparently contradictory needs.

In conclusion, the climatic differences proved to be more important to the initial debates over water rights doctrines than to the institutional structure that eventually resulted. The strength of the state government's commitment to the new system is highly significant. The legislative and judicial response to the legal protests was so firm and unified that the Code and the appropriation doctrine ceased to be an issue in Washington politics within a few years. In particular, business groups and capitalists interested in water resources were untroubled by the new state administrative role, and evidently considered it both to serve their interests and to promote an acceptable model of economic growth. The eventual decision of the power companies to stop opposing the Code can be understood in the same way: they wanted an end to the confusion and had a strong stake in overall regional economic investment and growth. The system of state permits to use water was a move toward centralized administrative control, and away from the judiciary with its traditional concem for private rights, but it solved part of the "problem" of private property in water. Water rights were still userights, but they were now more secure and predictable than they had been before, and thereby encouraged private investment.

22 West Side Irrigating Company v. Chase, Hydraulic Engineer (1921), 196 Pac 667; State v. McBee (1923), 215 Pac 347; Funk v. Bartholet, State Supervisor of Hydraulics (1930), 289 Pac 1018.

\section{Evolution of State intervention In irrigation and power development}

Shortly after the rationalization of water rights law in the mid 1920s, the nature of governmental intervention in irrigation and hydroelectric development underwent a transition. Intervention in these two forms of water use differed greatly and evolved slowly during the period from 1890 to 1930 , with very similar patterns at local, state, and Federal levels. For most of this period the amount of intervention was inversely related to the sector's economic vitality: that is, it was early and important in the case of irrigation, whose performance disappointed most hopes, and bitierly contested in energy production, whose growth exceeded all expectations. This reflected the traditional North American belief that the State should stay out of all economic activity in which private enterprise could make a profit. These priorities began to be reversed in the 1920 s, a period of growing political and economic crisis in U.S. capitalism.

a) Judicial policies in eminent domain law (expropriation of private property)

The Washington legislature, like that of other states, regularly tried to facilitate economic development by delegating its eminent domain power -i.e., the power to expropriate or "condemn" private property, with compensation - to certain private enterprises (sec section III above). On constitutional grounds, the courts would not approve this unless it was for a "public use or purpose," which over a 25-year period the State Supreme Court interpreted in such a way as to establish a clear preference for irrigation over hydroelectric development.

In 1899 the legislature passed companion statutes (Chapters 130 and 131) giving both lumber companies and irrigators the power to condemn property as nceded for rights-of-way. In 1903, in its first major decision in this area, the Court overturned the former statute and flatly rejected the argument that an expanding private lumber industry generated "public" benefits:

"It cannot be that, within the meaning of the Constitution, the distinction between public policy and public use is to be obliterated.... The use under consideration must be either a use by the public, or by some agency which is quasi-public, and not simply a use which may incidentally or indirectly promote the public interest or general prosperity of the state." 23

${ }^{23}$ Healy Lumber Company' v. Morris (1903), 74 Pac 681, 684-5. 
From 1905 to 1927, the Court applied the same logic to deny private power companies the right to condemn land for damsites and reservoirs. Since they were producing electricity for commercial sale, either to private industry or to the public without public service obligations, they could not justifiably be given such legal privileges. ${ }^{24}$

Irrigators got different treatment, however. In 1904 the Court confirmed the second statute without a blink, and in 1910 even extended the privilege to a private land speculation company; it was "immaterial" that the investors were speculating in canal systems rather than planning to actually raise crops, because "irrigation will promote the public good." The Court explained, in stark contrast to its earlier reasoning:

"The benefit to the public which supports the exercise of the power of eminent domain for purposes of this character, is not public service, but is the development of the resources of the state, and the increase of its wealth generally, by which its citizens incidentally reap a benefit."

This distinction was legally (if not economically) justified by the "vast difference between the use of water for manufacturing [i.e. power] and for irrigation. In the latter case there is no choice of means or location.... Not so with a manufacturing plant. The choice of location or motive power is one of economy or convenience at most." 25

This judicial policy continued into the 1920 s, receiving an added boost from the 1917 Water Code, which granted broad eminent domain powers "including the right and power to condemn an inferior use of water for a superior use." 26 In conflicts between irrigation and hydroelectric power, the Court considered the former to be "superior." 27

\footnotetext{
${ }^{24}$ The key decisions were State ex rel Tacoma Industrial Company v. Whitc River Power Company (1905), 82 Pac 150; State ex rel Harris v. Superior Court of Thurston County (1906), 85 Pac 666.

${ }^{25}$ Weed v. Goodwin (1904), 78 Pac 36; State ex rel Galbraith v. Superior Court of Spokane County (1910), 110 Pac 429, 433-4 The last quotation is from Tacoma lndustrial (see footote 24 above).

${ }^{26}$ This grant was remarkably broad, giving "any persoll...the right of eminent domain to acquire any property or tights... necessary for the storage of water for, or the application of water 10, any beneficial use" (Section 4 of the Water Code).

${ }^{27}$ See, for example, State ex rel Kennenick Irrigation District $v$. Superior Court for Walla Walla County (1922), 204 Pac 1.
}

This attitude finally changed in 1927 , by which time hydroelectric power had assumed new economic significance and State intervention was becoming politically more acceptable. When a private utility sought to condemn land to enlarge its reservoir at Lake Chelan in the eastern Cascades, planning to sell some of the electricity to private industry, the lower court followed the established precedents and denied the request. But the State Supreme Court overruled this decision "in view of the changed conditions of society." In the 22 years since the earlier decisions, it ruled:

"We have seen the uses [of electricity] multiplied a thousandfold, until there is scarcely an industry of any kind that has not felt the beneficial influence of electrical energy, and it can almost be said that its use is universal....[Therefore,] the use of electric energy for all purposes is a public use."

Noting that the state had created a Public Service Commission in 1911 to regulate private utilities' rates and services, the Court continued:

"The unfettered and untrammeled development [of water power]...is a thing much to be desired, and when this can be accomplished through public control and regulation... no decision of this court should stand in the way. The vanguard of progress moves steadily onward." 28

\section{b) Direct governmental involvement: irrigation}

These evolving judicial policies reflected the changing political and econon ic context. The statc government activciy supported irrigation development from 1889, mainly through its authorizalion and subsidy of special "irrigation districts." These districts were an attempt to promote capital investment while avoiding private monopolies, following the California model of a few years earlier (Pisani, 1984): they were local, quasi-public organizations formed voluntarily by local property owners in order to build, expand and maintain irrigation systems. The legislature granted these organizations several important legal privileges, including the power to use eminent domain, to tax their members, and to raise capital through the sale of public bonds (Department of Conservation and Development, 1987). Unfortunately, the success of those bond issues depended on the districts' financial condition, which like the rest of the

\footnotetext{
${ }^{28}$ State ex rel Chelan Electric Company v. Superior Court of Chelan County (1927), 253 Pac 115, 117-119 (emphasis added).
} 
agricultural sector was weak for most of the state's first half-century. ${ }^{29}$

To save the districts from collapse and prevent serious social and political unrest in eastem Washington, the legislature had to intervene year after year with direct subsidies and purchase of bonds, as well as continual financial reorganization. These concerns far outweighed the districts' actual construction activities. ${ }^{30}$ The financial pressures also induced the state, from 1915 to 1933 , reluctantly to give the districts increasing rights to develop and sell electricity to help meet expenses. The same pattern was evident in the state's plans for a major public irrigation project in the Columbia Basin: beginning in 1919 it promoted a design with a small and incidental amount of power generation, rejecting an alternative in which hydroelectric power was a central component. It changed its mind only in the late 1920 s in order to match the Federal government's growing emphasis on hydropower. ${ }^{31}$

Federal involvement in irrigation projects similarly came almost 30 years earlier than in hydropower. In 1902 the U.S. Congress passed the Reclamation Act ${ }^{32}$ in response to several decades of disappointing private irrigation development. (i.e., land reclamation). This Act set up a new government agency, the Reclamation Service, to plan and build irrigation projects, which were financed by the national budget but which were to be repaid by the farmers who were the beneficiaries. In Washington, the valleys east of the Cascade Mountains became the sites of several major Federal projects, chosen because of good soils and climate, proven agricultural

${ }^{29}$ See Clark, 1976; Dodds, 1986; Fahey, 1986. The only prosperous periods resulted from the Federal irrigation projects in 1905-1909 (see below) and the brief boom during World War I. From 1920 to 1938, irrigated acreage rose only $11 \%$, well under $1 \%$ per year. See the Bicnnial Reports of the State Hydraulic Engineer and Department of Conservation and Development, 1918-1946.

${ }^{30}$ This is evident both in the statules passed during this period and the Biemial Reports of the State Reclamation Board.

${ }^{31}$ For the irrigation districts this was first mentioned as a supplemental measure in a 1915 law (Chap. 179), thougl it was not until 1927 that they were authorized to use power sales 10 underwrite and repay bonds (State Reclamation Acl, Chap. 254). On the Columbia Basin project, see Harding, 1954, as well as Laws of 1919, Chap. 60, Laws of 1927, Chap. 260, and Laws of 1933, Chap. 81.

32 This Act concerned the reclamation of land by means of water development projects. Henceforth, this activity will be referred to as "land reclamation". productivity, and access to railroads. These projects accounted for nearly half of the state's expansion of irrigated acreage in 1900-1910, and nearly $100 \%$ of its irrigation storage capacity by 1920 (Coulter, 1951; Fahey, 1986). Unfortunately, low crop prices and high irrigation costs, in Washington and throughout the Western states, prevented farmers from repaying the Reclamation Service, which needed continuing infusions of cash from an unwilling Congress. Thus, the Service was on the verge of financial collapse in the 1920s (Gates, 1968).

c) Direct governmental involvement: hydroclectricity

State and Federal involvement in hydroelectric development was limited and controversial until the late 1920 s, as "public [electric] power" came to symbolize the larger political conflict over the proper role of government in the U.S. economy. In Washington State, however, there was an important "public power" movement at the local level. Soon after 1900 the state's two biggest cities, Seattle and Tacoma, created municipal utilities to produce energy -almost entircly hydroelectric - for public consumption and to contribute income to the city governments. These enierprises competed with private utilities inside city limits and became important symbols of public service in the early 20th century Progressive reform movement (Dodds, 1986; MacColl, 1979). By 1920 the two utilities produced $25 \%$ of the state's total hydropower ${ }^{33}$ and continued to expand and build new dams, arguing for the right to provide service beyond city limits. They were backed by a coalition of urban Progressives, labour unions, and farmers (some of the latter were populists and some werc simply frustrated at the private utilities' failure to provide rural services). In 1923 they got a bill to this effect passed by the kgislature and it was sent to a public referendum for approval.

The municipal utilities were bitterly atlacked by private power companies, which produced the remaining $75 \%$ of the state's hydropower. Two of these companies wcre most important, one in eastern Washington and onc in the west, each of which produced more than the city utilities combined. The private companies complained of unfair competition, since the city utilities were exempt both from paying taxes and from regulation by the Public Service Commission. Together with other business interests and political conservatives, the private utilities organized

\footnotetext{
${ }^{33}$ Bienmial Reports, 1917-1920, State Hydraulic Engincer.
} 
a massive publicity campaign against the bill, warning of a dangerous increase in governmental power and a threat to individual freedom, and thus succeeded in defeating the referendum (Fahey, 1986; Ficken, 1979).

Nonetheless, throughout the 1920 s public power remained a hot political issue. As the economy deteriorated and state finances came under severe pressure, total hydroelectric capacity nearly doubled and continued to rise, becoming an increasingly strategic and attractive policy concern. ${ }^{34}$ Finally in 1930, when the Great Depression had already begun, Washington voters approved a second and broader referendum, despite a similar opposition campaign warning of "socialism" (Washington Water Power Company, 1952). The new law authorized county-sized "Public Utility Districts" (PUDS), analogous to irrigation districts, which could produce and distribute electricity, issue bonds, levy taxes, and exercise eminent domain powers to condemn or force a linkage with private generation and distribution facilities (Laws of 1931, Chap. 31). The principle of public ownership and control was thus established, though for some years the economy remained too weak to allow any new development.

It was the Federal government's commitment to hydropower that eventually transformed Washington's economy and opened a nationwide era of large-scale, multiple-use water development. Federal policy was of decisive importance both because Federal law controlled all navigable waters -and thus the bigger rivers- and because many of the nation's most promising water-power sites, especially in the Western states, were on public lands. But deep political disagreement within Congress over the nature of the government's role created a stalemate for nearly 20 years, until finally the 1920 Water Power Act found a compromise, allowing Federal agencies to plan and build power dams but requiring them to lease the facilities to private utilities for the energy production itself (Hays, 1959).

Even so there was little actual development until the economic crisis of the 1930s, when part of President Franklin D. Roosevelt's "New Deal" included massive public works projects that were intended

\footnotetext{
${ }^{34}$ Capacity increased from 380000 to $700000 \mathrm{hp}$ between 1920 and $1928(84 \%$, or more than $10 \%$ per year), and then 10 1000000 hp by 1936 (an additional 43\%, or more than $5 \%$ per year at the height of the Depression). See Biennial Reports, 1920-1936, State Department of Conservation and Development.
}

both to provide public employment and to fuel regional economic development. To achieve the latter goal, Federal agencies drew on the hard lessons of previous decades by making hydroelectricity the central element in multiple-purpose water projects; in this "cash register dam" strategy, power revenues were used to subsidize less economically viable water uses such as irrigation, flood control, and recreation. The Bureau of Reclamation (the new name of the Reclamation Service), in particular, followed this strategy to save itself from being abolished, thereby entering upon several decades of bureaucratic growth and prosperity, even though irrigation remained its official purpose (Gates, 1968; Swain, 1970).

In Washington the Federal government built two big dams in the 1930s, named Bonneville and Grand Coulee, both on the Columbia River in the eastern part of the state. Finished in 1937 and 1941, respectively, they more than trebled the state's total power production. ${ }^{35}$ The Bonneville Power Administration (BPA), an independent Federal agency, was established in 1937 to stimulate regional economic development by distributing this huge energy surplus, using and expanding the existing transmission network, and encouraging public consumption by offering very low wholesale prices to Public Utility Districts, municipal utilities, and rural electric cooperatives. The PUDS were thus relieved of the capital-intensive burden of production, allowing them to expand rapidly for the first time since they had been authorized in 1931 and even take over some existing private distribution facilities (Pacific Northwest Public Power Records Survey, 1981; Washington Water Power Company, 1952). The BPA became a major symbol of both President Roosevelt and the New Deal, representing the crucial role of government in boosting economic and social welfare, and providing a standard of comparison for the rates, services and operations of the private utilities. ${ }^{36}$ At the time, however, there was no demand for such large quantities of energy, and the need to stimulate both distribution and consumption soon led the BPA to work closely with private utilities and sell them power at the same wholesale prices.

\footnotetext{
${ }^{35}$ Total state production rose from 2.9 billion kwh in 1935 to 10.0 billion in 1943, almost entirely attributable to those two dams. State Planning Council, 6th Report, 1934-44.

${ }^{36}$ The BPA's first director was a leading flgure in the regional "public power movement," who had directed the dramatic expansion of Seattle City Light for 25 years; at his death he was described as a man "whose love for mankind expressed itself in kilowatts" (MacColl, 1979, p. 561).
} 
The Federal dams and the BPA made possible a regional economic transformation during and after the Second World War, based on a boom in energyintensive industries such as metallurgy, aluminumsmelting, shipyards and airplane-manufacturing. This established lasting geographic patterns and determined the course of water resource development to the present day. After the war Federal agencies built ten more big dams in eastern Washington and 15 others elsewhere in the Columbia River basin, in Idaho and Oregon. Some of these provided water for new irrigation development, including hundreds of thousands of acres in the Columbia Plain, but the first priority and driving force was electricity: generated in the arid East of the state, but mostly exported to western Washington and out-of-state (Butcher and Wandschneider, 1986). Thus, after half a century of statehood, Washington's economy had become heavily dependent on water-power and Federal intervention.

\section{VII}

\section{Conclusions relevant to}

\section{Latin America}

This case study offers several lessons about property rights and the role of the State in water resources that are relevant to Latin America today.

First, geographic conditions seem to have a less determining influence on the nature of water rights than is commonly believed. Although in Washington the debate over water rights doctrines was often put in terms of the climatic differences between the eastern and western halves of the state, the essential issue was the security of title needed to attract private capital investment. Given that security, regional economic dynamics were much more important than either the geographic basis of legal doctrine or the climate itself in determining the course of water resource development. A key illustration of this is that the hard-fought implementation of a Water Code supposedly designed for the needs of arid-country agriculture was almost immediately followed by the rise to dominance of water-power for urban and industrial purposes -with the bulk of that energy produced in the arid part of the state.

Second, the nature of private property under capitalism is more ambiguous than either its proponents or opponents often realize. The security of private rights necessary to stimulate capital investment in Washington was only achieved at the expense of other property rights that were equally private and equally market-oriented, but less amenable to maximized economic growth or capital accumulation. For political, economic and social reasons, therefore, it may be necessary to favour some kinds of private property but not others, and arguments supporting one kind do not necessarily support another -a point which is usually lost in both ideological and pragmatic debates.

Third, the evolution of the Washington water rights regime highlights both the historical and continuing dependence of private property and capital accumulation on State intervention. Although private rights to water became defined as administrative permits for its use, these functioned in fact as a capitalist form of private property, encouraging capital investment and market-oriented economic development. Such a system is absolutely dependent on continued State maintenance of its rules, premises and practical necessities: resolving conflicts, gathering and keeping technical data and legal information, and so forth. Thus "property," like "the market", must not only be understood as a socially and collectively created institution -it must also be appreciated that it cannot successfully function otherwise.

Fourth, the crucial importance of State involvement in both types of water development is evident. In Washington, both state and national governmental activity began as a reaction to economic conditions -to the stagnation of irrigated agriculture on one hand, and to the promise of hydroelectricity on the other- but once established it then became the sine qua non of regional growth. Furthermore, the integrated and multiple-purpose character of water use was due entirely to central governmental control. 
Finally, the property regime adopted in Washington -i.e., a combination of investmentoriented private rights with centralized State administration and control- was able to overcome the main obstacles posed by water to private property (see section IV). The fact that water rights were still use-rights, and that water uses were qualitatively different from each other and inextricably related, did not prevent the establishment of institutions intended to fully incorporate the resource into the process of capitalist economic development. This effort was so effective that it casts doubt on the limited character of much of today's debate about "environmentally sustainable development": if the goal is to incorporate the logic, qualities and relationships of ecological systems into existing political and economic models, the necessary institutional and structural reforms will have to be truly fundamental.

\section{Bibliography}

Ackerman, Bruce (ed.) (1975): Economic Foundations of Property Law, Boston, MA, Little, Brown \& Co.

Bardhan, Pranab (1989): Alternative approaches to the theory of institutions in economic development, in P. Bardhan (ed.), The Economic Theory of Agrarian Institutions, Oxford, Clarendon Press.

Bromley, Daniel (1982): Land and water problems: an institutional perpsective, American Journal of Agricultural Economics, vol. 64, p. 834 et seq., Lexington, KY, American Agricultural Economics Association (AAEA).

Butcher, Norman and Philip Wandschneider (1986): Competition between irrigation and hydropower in the Pacific Northwest, in Kenneth Frederick (ed.): Scarce Water and Institutional Change, Washington, D.C., Resources for the Future.

Clark, Norman (1976): Washington: a Bicentennial History, New York, Norton.

Cooter, Robert and Thomas Ulen (1988): Law and Economics, Glenview, IL, Scott, Foresman.

Coulter, Calvin (1951): The victory of national irrigation in the Yakima Valley, 1902-06, Pacific Northwest Quarterly, vol. 42, p. 99 et seq.

Department of Conservation and Development (1987): Irrigation, Diking, Drainage, and Reclamation Districts, 1919-55, Olympia, WA, Department of Conservation and Development.

Dodds, Gordon (1986): The American Northwest: a History of Oregon and Washington, Arlington Heights, IL, Forum Press.

Dunbar, Robert (1983): Forging New Rights in Western Waters, Lincoln, NE, University of Nebraska Press.

ECLAC (Economic Commission for Latin America and the Caribbean) (1989): La gestion de los recursos hidricos en América Latina y el Caribe, "Estudios e Informes de la CEPAL" series, No.71, Santiago, Chile, April. United Nations publication, Sales No. S.89.II.G.9.

Fahey, John (1986): The Inland Empire: Unfolding Years, 1879-1929, Seattle, WA, University of Washington Press.
Ficken, Robert (1979): Lumber and Politics: the Career of Mark E. Reed, Santa Cruz, CA, Forest History Society.

Gates, Paul (1968): History of Public Land Law Development, Washington, D.C., Public L and Review Commission.

Harding, Robert (1954): Water from Pend Oreille, Pacific Northwest Quarterly, vol. 45, p. 52 et seq.

Hays, Samuel (1959): Conservation and the Gospel of Efficiency: the Progressive Conservation Movement, 1890-1920, Cambridge, MA, Harvard University Press.

Horwitz, Morton (1977): The Transformation of American Law, 1780-1860, Cambridge, MA, Harvard University Press.

Hurst, James Willard (1956): Law and the Conditions of Freedom in the 19th Century United States, Madison, WI, University of Wisconsin Press.

MacColl, E. K. (1979): The Growth of a City: Power and Politics in Portland, Oregon, 1915-50, Portland, OR, Georgian Press.

MacPherson, C. B. (ed.) (1978): Property: Mainstream and Critical Positions, Toronto, University of Toronto Press.

Morris, Arval (1956): Washington water rights - a sketch, Washington Law Review, vol. 13, p. 243 et seq.

Pacific Northwest Public Power Records Survey (1981): Guide to Historical Records of Pacific Northwest Public Power Utilities, Seattle, WA, Pacific Northwest Public Records Survey.

Pisani, Donald (1984): From the Family Farm to Agribusiness: the Irrigation Crusade in California and the West, 1850-1931, Berkeley, CA, University of California Press.

Posner, Richard (1977): Economic Analysis of Law, Boston, MA, Little, Brown \& Co.

Ramos, Joseph (1991): Más alla de la economía, más acá de la utopia, Santiago, Chile, Economic Research Corporation for Latin America (CIEPLAN).

Reeve, Andrew (1986): Property, London, Macmillan.

Scheiber, Harry (1973): Property law, expropriation, and resource allocation by government, 1789-1910, Journal of Economic History, vol. 33, p. 232 et seq. 
Scheiber, Harry and Charles McCurdy (1975): Eminent domain law and Western agriculture, Agricultural History, vol. 49, p. 112 et seq.

Swain, Donald (1970): The Bureau of Reclamation and the New Deal, 1933-40, Pacific Northwest Quarterly, vol. 61, p. 137 et seq.

United Nations/ECLAC/UNEP (United Nations Environment Programme) (1980): Agua, desarrollo, y medio ambiente en América Latina, Santiago, Chile, July.
Washington Water Power Company (1952): The I'ublic Utility Districts of Washington State: Promises Compared with Performance, Spokanc, WA, Washington Water Power Company.

Webb, Walter Prescott (1931): The Great Plains, Boston, MA, Ginn \& Co.

Worster, Donald (1985): Rivers of Empire: Water, Aridlity, and the Growth of the American West, New York, NY, Pantheon Books. 